\title{
Pemodelan Sistem Dinamik untuk Prediksi Intensitas Hujan Harian di Kota Malang
}

\author{
Philip Faster Eka Adipraja ${ }^{1}$, Danang Arbian Sulistyo \\ ${ }^{1,2}$ STMIK ASIA Malang \\ ${ }^{1}$ philipfaster@gmail.com, ${ }^{2}$ danangarbian@gmail.com
}

\begin{abstract}
ABSTRAK. Kota Malang yang berada di dataran tinggi tidak luput dari bencana banjir yang setiap tahun jumlah kejadiannya semakin tinggi. Hal ini disebabkan oleh banyak faktor, seperti intensitas hujan harian yang tinggi ditambah dengan kurang optimalnya pembangunan infrastruktur yang ada. Dalam hal ini untuk mitigasi jumlah kejadian banjir, langkah awal yang mudah yaitu memprediksi intensitas hujan hariannya. Sehingga hasil prediksi dapat digunakan oleh para pemangku kepentingan untuk mitigasi kejadian banjir di Kota Malang pada tahun-tahun berikutnya. Penelitian ini bertujuan untuk membuat model sederhana dalam memprediksi intensitas hujan selama jangka waktu tiga tahun yaitu 2018-2020. Pemodelan dan simulasi dilakukan menggunakan pendekatan sistem dinamik yang dapat memodelkan sistem dengan dinamika yang kompleks. Model intensitas hujan yang dikembangkan mengintegrasikan faktor yang berpengaruh seperti kelembaban dan temperatur. Hasil validasi model intensitas hujan menunjukkan error nilai $E 1$ sebesar $3.86 \%$ dan E2 sebesar $4.13 \%$ dengan hasil RMSE menunjukkan angka 8.4452.
\end{abstract}

Kata Kunci: Pemodelan; Sistem Dinamik; Intensitas Hujan; Kota Malang;

ABSTRACT. Malang city located in the highlands that is not spared from the flood disaster which the number of events is increasing every year. This is due to many factors, such as the high intensity of daily rainfall coupled with less optimal infrastructure development. In this case, to mitigate the number of flood events, an easy first step is to predict the daily rain intensity. So that the prediction result can be used by the stakeholders to mitigate flood incident in Malang Cityin the following years. This study aims to create a simple model in predicting rain intensity over a three year period of 20182020. Modeling and simulation are done by using a system dynamics approach that can model the system with complex dynamics. The developed model of rain intensity integrates influencing factors such as humidity and temperature. The rainfall intensity model has validated with the error of $E 1$ value is $3.86 \%$ and $E 2$ is $4.13 \%$ and with RMSE result indicates the number of 8.4452 ..

Keywords: Modelling; System Dynamics; Rain Intensity; Malang City;

\section{PENDAHULUAN}

Kota Malang berlokasi 440-667 meter diatas permukaan lautdan memiliki total luas sebesar 11.006 hektar. Saat ini Kota Malang memiliki lahan pertanian sebesar 29,5\% dengan komoditas tanaman pangan utama yaitu padi sawah, jagung, ubi kayu, dan kacang tanah.Jumlah penduduk Kota Malang sekitar 851.298 jiwa dan dengan laju pertumbuhan sekitar $0,75 \%$ per tahun selain berprofesi sebagai petani dan pegawai pemerintah, juga memiliki sekitar 3045 industri kecil dan menengah yang jumlahnya meningkat setiap tahun(BPS Kota Malang, 2016). Selain itu, Kota Malang semakin diramaikan dengan meningkatnya sektor pariwisata(Sasongko, 2017).

Dengan tingginya potensi positif yang dimiliki, ternyata Kota Malang juga kerap dilanda bencana alam. seperti banjir (Adhi, 2014) yang jumlah kejadiannya terus mengalami peningkatan, khususnya di beberapa kecamatan seperti Blimbing, Sukun, Kedungkandang, Lowokwaru, dan Klojen(Abidin, 2017). Banjir tersebut merupakan bencana alam yang sering terjadi di perkotaan maupun Daerah Aliran Sungai (DAS) dan menyebabkan dampak terhadap potensi masyarakat, ekonomi, infrastruktur, maupun lingkungan(Zhou, Leng, \& Huang, 2018).Hal tersebut dapat disebabkan oleh perubahan iklim yang tidak menentu seperti meningkatnya curah hujan maupun intensitas hujan (Pabalik, Ihsan, \& Arsyad, 2015)dan juga kurang optimalnyapembangunan infrastruktur (Chang et al., 2013) serta penataan ruang terbuka hijau Kota Malang (Hayat, 2014).

Dengan semakin meningkatnya jumlah bencana banjir di Kota Malang, memperkirakan kapan terjadinya banjir merupakan suatu tantangan tersendiri. Dimana usaha mitigasi banjir yang berpacu dengan waktu yang terbatas dapat meminimalisir korban jiwa maupun kerugian lain (Tekeli, 2017).Banyak penelitian yang menyimpulkan bahwa banjir dipengaruhi oleh faktor-faktor meteorologi seperti tingginya curah hujan maupun intensitas hujan(Dube et al., 2014; Schumacher, 2016; Tekeli, 2017). Maka dengan adanya prediksi curah hujan maupun intensitas hujan merupakan satu langkah maju dalam usaha memperkirakan banjir datang. 
Saat ini dengan data series yang ada, telah banyak penelitian yang dilakukan untuk memprediksi curah hujan dengan akurasi yang cukup tinggi menggunakan berbagai metode seperti Improved Global Forecast System (GFS), Multi LayerPerceptrons (MLP), maupunArtificial Neural Network (ANN)(Hiteshri, Subimal, \& Subhankar, 2017; Khedhiri, 2015; Khidir, Adlan, \& Basheir, 2013). Di lain sisi, intensitas hujan masih minim penelitian, dan sebagian besar menggunakan teknologi spasial maupun citra satelit (Cooley \& Chang, 2017; Kigawa, 2014; Morin, Krajewski, Goodrich, Gao, \& Sorooshian, 2003) dan dengan mempertimbangkan beberapa faktor yang ada. Dalam hal ini, penelitian intensitas hujan yang ada hanya dapat memprediksi dengan akurat dalam jangka pendek.

Menindaklanjuti peluang tersebut, penelitian ini berfokus pada pembuatan model sederhana untuk prediksi intensitas hujan di Kota Malang. Pembuatan model tersebut akan menggunakan beberapa faktor lain seperti temperaturdan kelembaban udara. Dengan adanya variabel dinamis yang ada, pembuatan model dilakukan dengan pendekatan sistem dinamik. Pendekatan sistem dinamik pernah dilakukan untuk memprediksi curah hujan hingga prediksi musim tanam kentang dengan error yang kecil yaitu sekitar satu hingga dua minggu (Wahyuni, Adipraja, \& Mahmudy, 2018). Selain itu pendekatan ini juga pernah dilakukan untuk menilai elemen-elemen pengembangan alat dalam prakiraan cuaca yang dapat meningkatkan hasil verifikasi alat tersebut (Rajasekaram, McBean, \& Simonovic, 2010). Oleh sebab itu, diharapkan pendekatan sistem dinamik dapat digunakan untuk memprediksi intensitas curah hujan dengan sederhana dan dengan tingkat error yang minim.

\section{METODE}

\subsection{Sistem Dinamik}

Hingga saat ini sistem dinamik banyak digunakan sebagai metode untuk sistem prediksi dan pembuatan kebijakan baru terkait hasil prediksi. Sistem dinamik dapat menghasilkan prediksi yang lebih baik dalam tren jangka pendek, menengah, maupun jangka panjang daripada model statistik yang mengarahkan pada keputusan yang lebih baik. Sistem dinamik juga menyediakan sarana untuk mengidentifikasivariabelvariabel yang berpengaruh dalam sistem yang melibatkan dinamika yang kompleks(Lyneis, 2000).

Pendekatan dinamika sistem diawali oleh pendefinisian masalah secara dinamis. Membuat konsep dari sistem nyata yang berisikan variabel-variabel yang saling berhubungan timbal balik. Konsep awal tersebut dapat dituangkan ke dalam Causal Loop Diagram (CLD). Setelah CLD selesai dikonsepkan, selanjutnya mengidentifikasi stok atau akumulasi independen dalam sistem dan aliran arus masuk maupun keluar. Identifikasi tersebut dirumuskan dalam model behavioral yang mampu mereproduksi masalah dinamis dalam cakupan yang telah ditentukan. Model ini merupakan model simulasi yang dibuat menggunakan komputer dalam persamaan linear yang biasa disebut Stock and Flow Diagram (SFD). (Richardson, 2013)

Model yang dikembangkan harus melalui pengujian sebelum dianggap valid sesuai dengan sistem nyata. Pengujian dilakukan dengan tahapan verifikasi dan validasi. Saat model disimulasikan, perlu diverifikasi bahwa model sudah terbebas dari bug maupun kesalahan logika pemrograman lainnya dan dapat berjalan tanpa ada error. Selanjutnya, hasil simulasi perlu divalidasi dengan system atau data aktual, yaitu dengan menggunakan perbandingan rata-rata $(E 1)$ dan perbandingan variasi amplitudo $(E 2)$.

$$
E 1=\frac{\lfloor\bar{S}-\bar{A}\rfloor}{\bar{A}} * 100 \%
$$

$\bar{S}=$ nilai rata-rata hasil simulasi

$\bar{A}=$ nilai rata-rata data

Hasil simulasi dari model yang dikembangkan dapat dikatakan valid apabila nilai $E 1$ kurang dari $5 \%$ dan E2kurang dari 30\%. (Barlas, 1996). Validasi E1dapat dihitung menggunakan rumus (1) dan untuk validasi $E 2$ dapat dihitung menggunakan rumus (2).

$S s=$ nilai rata-rata hasil simulasi

$$
E 2=\frac{|S s-S a|}{S a} * 100 \%
$$

$S a=$ nilai rata-rata data

Selain validasi menggunakan $E 1$ dan $E 2$, dalam artikel ini juga digunakan satu lagi validasi untuk melihat akurasi dalam data intensitas curah hujan, yaitu menggunakan Root Mean Square Error (RMSE) (Chai \& Draxler, 2014). 
Hasil simulasi dari pengembangan model yang telah divalidasi dapat digunakan untuk memprediksi intensitas curah hujan dalam beberapa tahun mendatang. Dalam penelitian ini, simulasi akan digunakan untuk memprediksi tiga tahun ke depan yaitu tahun 2018, 2019, dan 2020.

\subsection{Data}

Data yang dipergunakan dalam penelitian ini berupa data rata-rata intensitas hujan, temperatur dan kelembaban Kota Malang yang diperoleh dari Badan Meteorologi, Klimatologi, danGeofisika (BMKG) Karangploso. Data tersebut diolah dan dimasukkan menjadi data bulanan dalam 5 tahun terakhir (2013-2017) dan diperoleh nilai rata-rata, minimum, maksimum, dan standar deviasi.

Dari data intensitas hujan yang telah diambil, pola data menunjukkan siklus musiman dimana dalam 5 tahun terakhir memiliki pola yang sama. Rata-rata intensitas hujan tertinggi terjadi pada bulan April dan hampir tidak pernah hujan pada bulan Agustus. Grafik rata-rata intensitas hujan ditunjukkan pada

Gambar 1. Data intensitas hujan ini nantinya akan digunakan sebagai data acuan dalam memvalidasi hasil simulasi dari model yang telah dikembangkan.

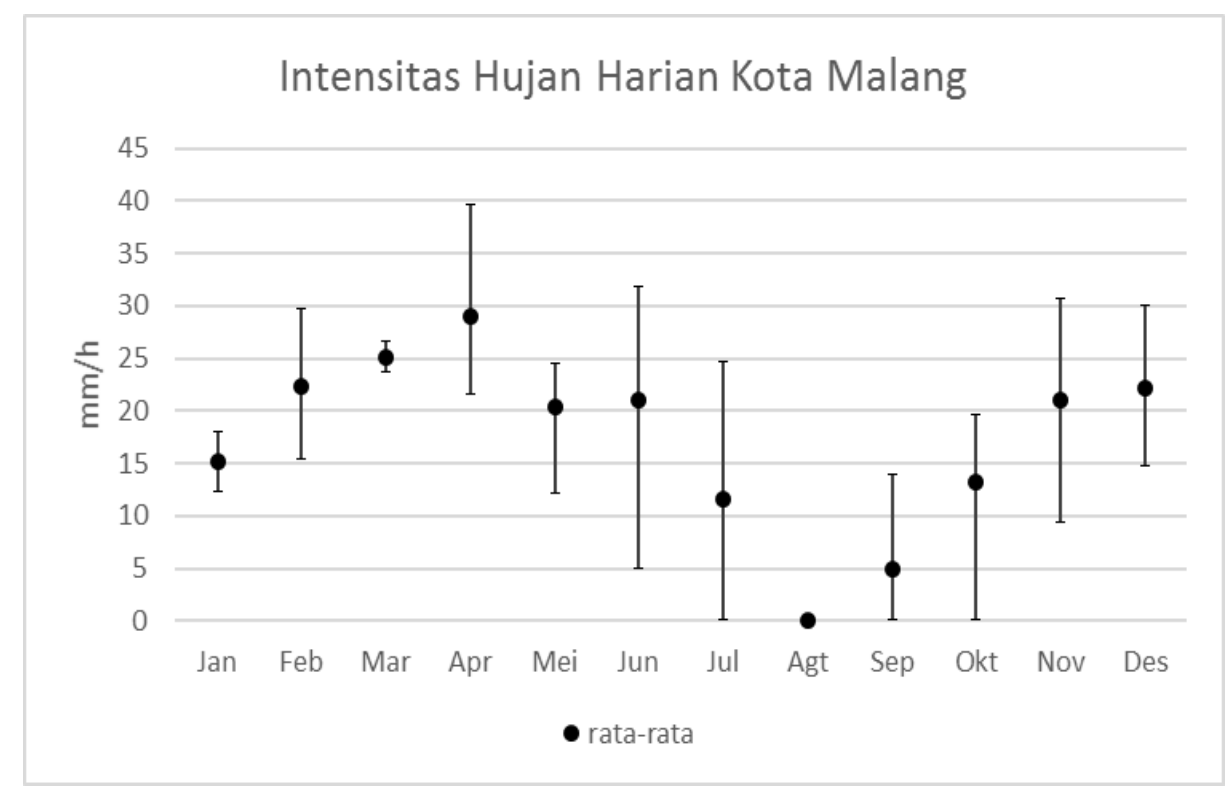

Gambar 1. Rata-rata intensitas hujan harian di Kota Malang $(\mathrm{mm} / \mathrm{h})$

Temperatur di Kota Malang tidak berubah secara signifikan setiap bulannya dengan rata- rata temperature sekitar $23.7^{\circ} \mathrm{C}$. Namun temperature terendah dapat terjadi di bulan Juli dan temperature tertinggi dapat terjadi di bulanOktober. Grafik rata-rata temperatur Kota Malang dapat dilihat pada Gambar 2. 


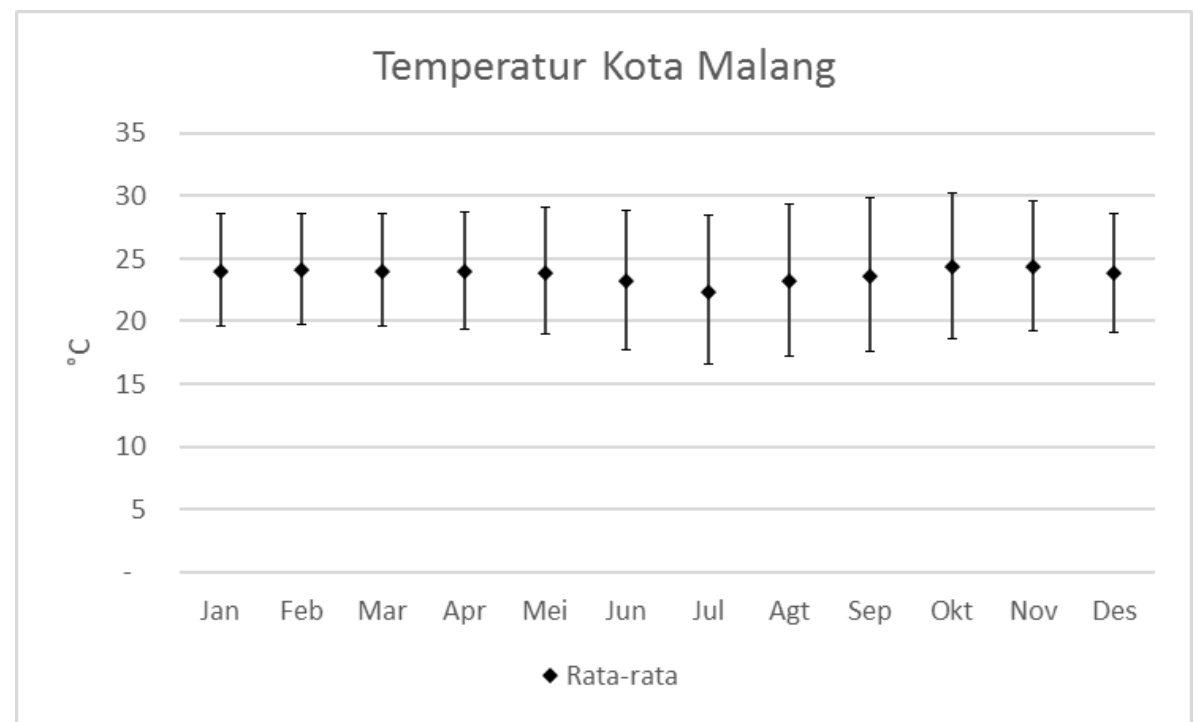

Gambar 2. Rata-rata temperatur di Kota Malang $\left({ }^{\circ} \mathrm{C}\right)$

Di lain sisi, kelembaban Kota Malang terlihat memiliki pola data yang menunjukkan siklus musiman dengan kelembaban tertinggi pada bulan Februari dan terendah pada bulan September. Grafik rata-rata kelembaban Kota Malang dapat dilihat padaGambar 3.

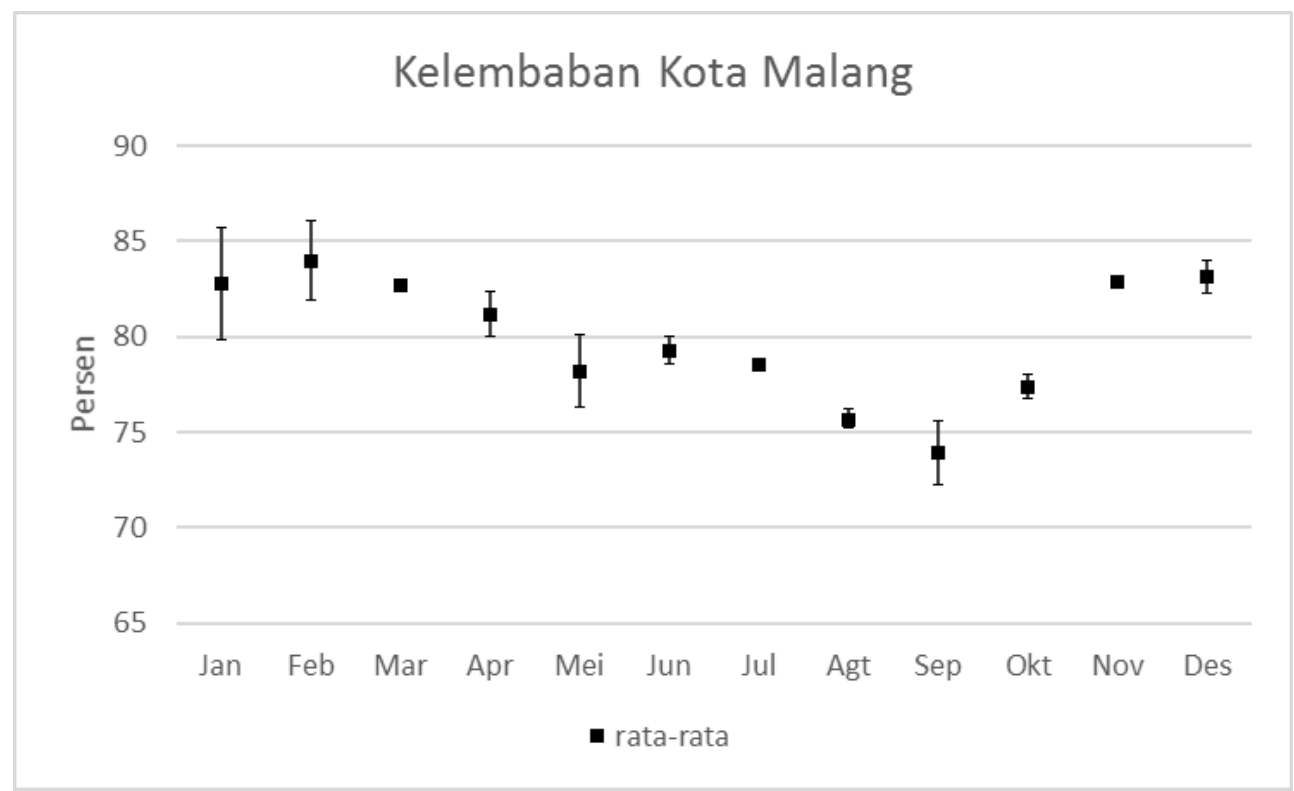

Gambar 3. Rata-rata kelembaban di Kota Malang (\%)

\subsection{ModelIntensitas hujan}

Secara umum, intensitas hujan didefinisikan sebagai volume hujan yang jatuh dalam interval waktu tertentu, biasanya dalam satuan $\mathrm{mm}$ per jam $(\mathrm{mm} / \mathrm{h})$ (Cooley \& Chang, 2017). Tinggi rendahnya intensitas hujan ini dipengaruhi oleh variabel-variabel meteorologi lainnya, seperti temperatur dan kelembaban(Pielke et al., 2018). Pada penelitian yang dilakukan di Amerika Serikat bagian timur, menunjukkan bahwa temperatur merupakan salah satu faktor yang berpengaruh pada intensitas hujan (Lepore, Veneziano, \& Molini, 2015). Selain itu penelitian yang dilakukan di Inggris, kelembapan atmosfer tertentu akan mempengaruhi presipitasi/hujanharian. Di wilayah Inggris bagian tenggara, kelembaban memiliki berkontribusi hingga $60 \%$ pada intensitas hujan harian yang berbeda selama beberapa bulan (Allan, Lavers, \& Champion, 2016). 


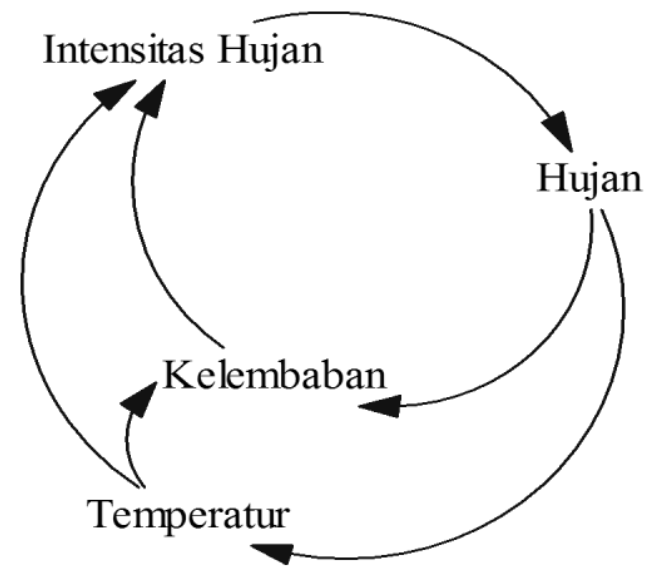

Gambar 4. CLD Intensitas hujan

Berdasarkan pembahasan tersebut, dapat dikembangkan sebuah model umpan balik informasi dalam CLD yang ditunjukkanpadaGambar 4. Secara langsung dapat disimpulkan bahwa temperatur dan kelembapan akan mempengaruhi intensitas hujan, dimana hujan yang turun akan kembali mempengaruhi kelembapan dan temperatur(Cong \& Brady, 2012).Konsep yang telah dituangkan dalam CLD dikembangkan menjadi model SFD untuk prediksi intensitashujanyang disimulasikanmenggunakankomputer.

Hasil pengolahan data aktual kelembaban yang diperoleh dari BMKG menunjukkan bahwa rata-rata kelembaban akan berubah setiap bulan dengan pola yang sama setiap tahunnya. Oleh karena itu, dalam model simulasi yang dikembangkan, variabel kelembaban dikategorikan dalam hitungan bulan. Setiap bulan akan bernilai acak yang memiliki parameter minimum, maksimum, rata-rata, dan standar deviasi yang berbeda-beda.Variabel kelembaban bulanan tersebut digabung dalam satu variabel yang nanti berisikan hasil simulasi mulai bulan januari hingga desember yang ditunjukkanolehGambar $\mathbf{5}$.

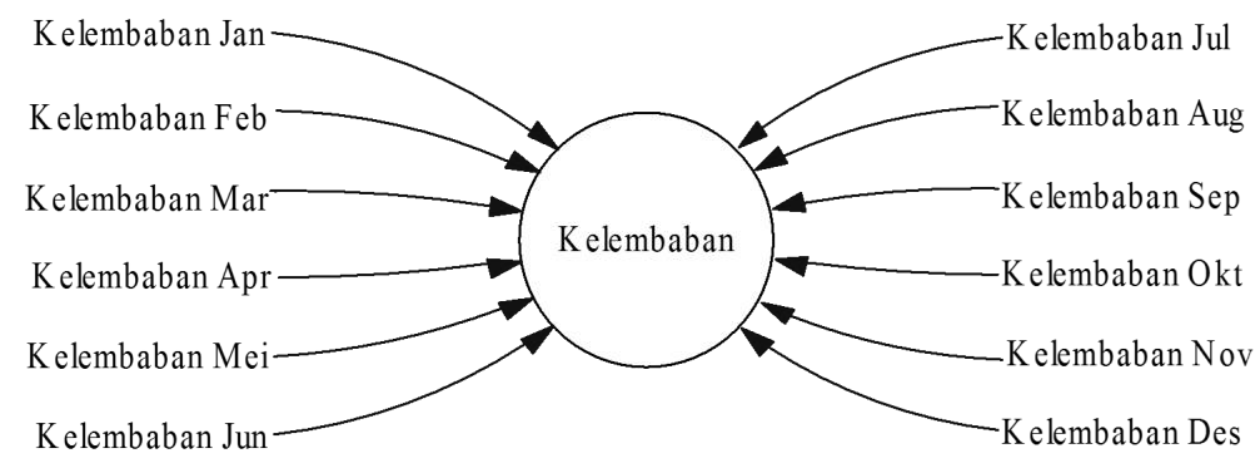

Gambar 5. Model SFD kelembaban

Dalam variabel temperatur, meski data tidak berubah terlalu besar setiap bulannya, namun tetap memiliki perbedaan nilai setiap bulannya dengan pola data yang sama setiap tahunnya. Oleh karena itu, variabel temperatur dalam model yang dikembangkan tetap dikategorikan dalam hitungan bulan. Setiap bulan akan bernilai acak yang memiliki parameter minimum, maksimum, rata-rata, dan standar deviasi yang berbeda-beda. Variabel temperatur bulanan tersebut digabung dalam satu variabel yang nanti berisikan hasil simulasi mulai bulan januari hingga desember yang ditunjukkan oleh Gambar 6 . 


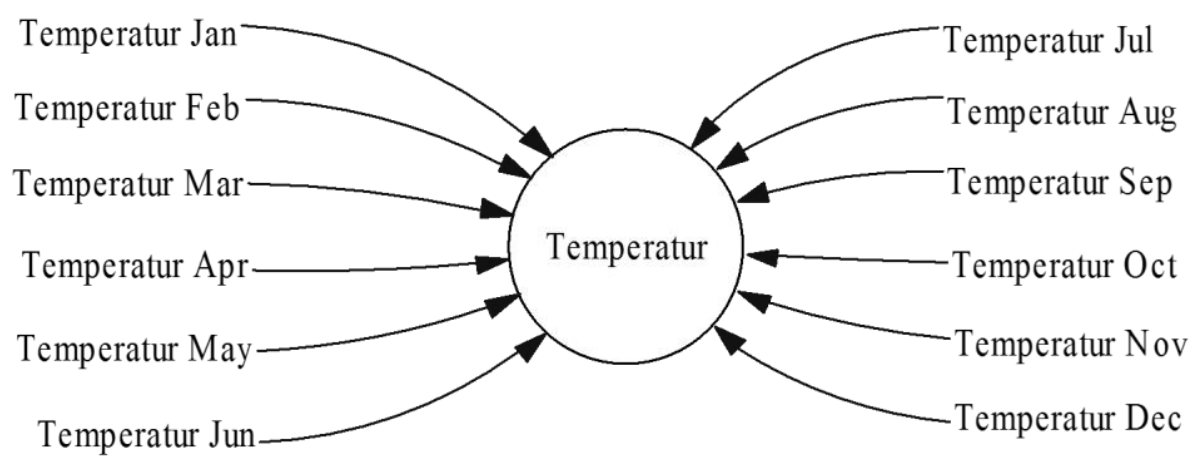

Gambar 6. Model SFD temperatur

Selain variabel kelembaban dan temperatur, dikembangkan juga satu variabel bernama rate dasar untuk presipitasi. Dimana variabel ini merupakan hasil pengolahan awal variabel intensitas hujan (presipitasi) sebelum diintegrasikan dengan nilai dari pengaruh kelembaban dan temperatur. Variabel ini dikategorikan dalam hitungan bulan. Setiap bulan akan bernilai acak yang memiliki parameter minimum, maksimum, ratarata, dan standar deviasi yang berbeda-beda sesuai dengan data intensitas hujan. Variabel rate dasarpresipitasibulanantersebutdigabung dalam satu variabel yang nanti berisikan hasil simulasi mulai bulan januari hingga desember yang ditunjukkan oleh Gambar 7.

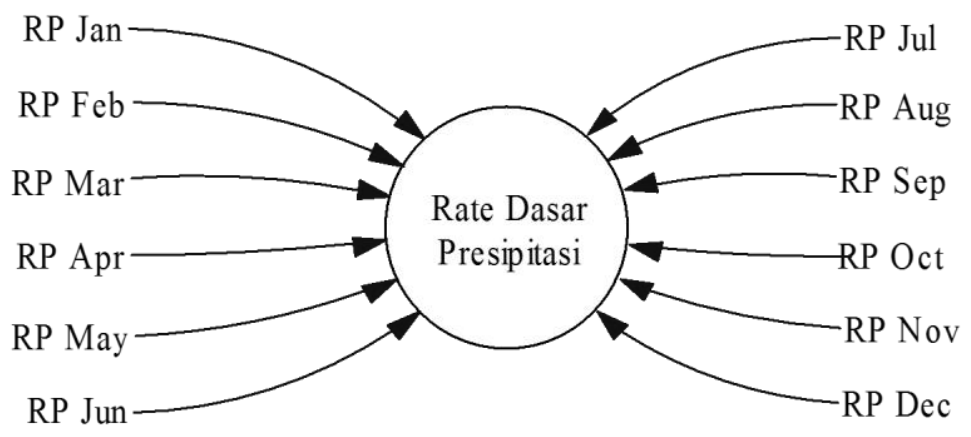

Gambar 7. Model SFD ratedasarpresipitasi

Terakhir, dimana variabel intensitas hujan merupakan hasil output yang nantinya akan disimulasikan dan divalidasi dengan data aktual. Pemodelan intensitas hujan ini menggunakan dua buah variabel yang mempengaruhinya, yaitu temperatur dan kelembapan.

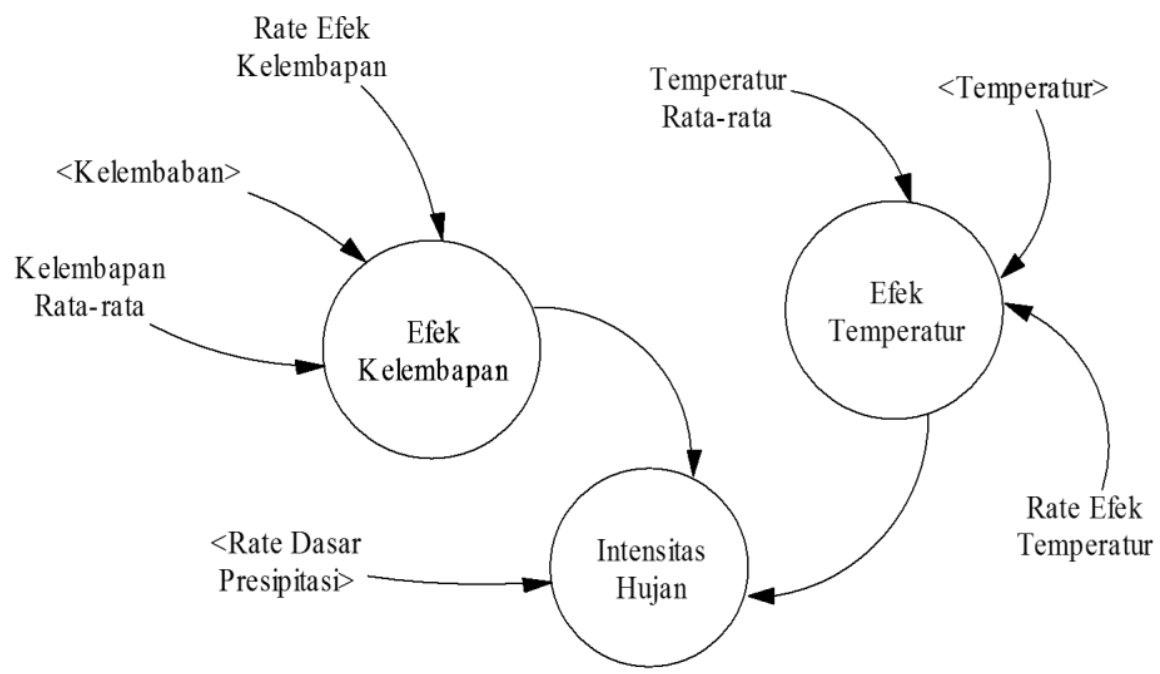

Gambar 8. Model SFD intensitas hujan dengan pengaruh kelembapan dan temperatur

Temperatur menyebabkan kenaikan daya ikat air dalam udara sebesar $\sim 6-7 \%$ setiap kenaikan temperatur sebesar $1^{\circ} \mathrm{C}$ (Buishand \& Brandsma, 1999; Frei, Schär, Lüthi, \& Davies, 1998; Trenberth, 2005). 
Selain itu, kelembapan di permukaan akan meningkat $4.3 \%$ setiap perubahan temperatur sebesar $1^{\circ} \mathrm{C}(\mathrm{Fadli}$, 2012). Gambar 8 menunjukkan model intensitas hujan yang dihitung dari rate dasar presipitasi yang dipengaruhi oleh efek kelembaban dan efek temperatur.

\section{HASIL DAN PEMBAHASAN}

Proses simulasi pemodelan intensitas hujan yang telah dikembangkan dilakukan dengan perangkat lunak ventana simulator. Hasil simulasi telah menghasilkan data intensitas hujan rata-rata mulai tahun 2013 hingga 2017. Hasil simulasi untuk tahun 2013 hingga 2017 dapat dilihat pada Gambar 9.

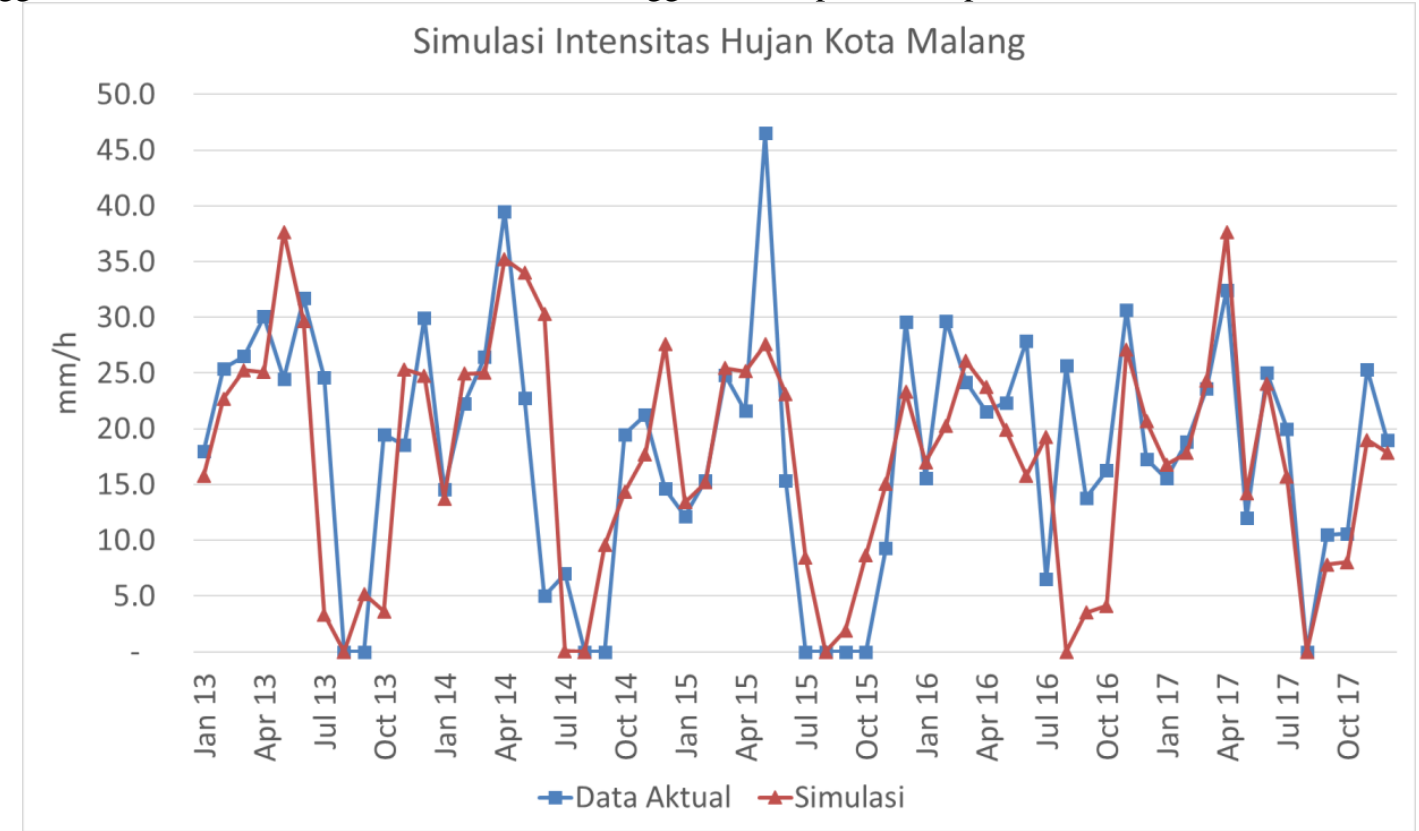

Gambar 9. Hasil simulasi intensitas hujan rata-rata untuk tahun 2017

Terlihat pada Gambar 9 bahwa hasil simulasi dengan data aktual tidak jauh berbeda. Terlebih lagi, simulasi dari pemodelan ini telah divalidasi $E 1$ dan $E 2$ dengan error yang kecil. Variabel yang divalidasi yaitu variable kelembaban, temperatur, dan intensitas hujan.

Tabel 1. Validasi model intensitas hujan

\begin{tabular}{lccc}
\hline No & Variabel & Validasi & Status \\
\hline 1 & Kelembaban & $E 1=\frac{\lfloor 80.02-79.96\rfloor}{79.96} * 100 \%$ & E1Valid \\
$E 1=0.0009 * 100 \%=0.09 \%$ & \\
$E 2=\frac{\lfloor 3.31-3.51\rfloor}{3.51} * 100 \%$ & $E 2$ Valid \\
$E 2=0.0567 \times 100 \%=5.67 \%$ &
\end{tabular}

2 Temperatur

$$
\begin{aligned}
& E 1=\frac{\lfloor 23.88-23.89\rfloor}{23.89} * 100 \% \\
& E 1=0.0003 * 100 \%=0.03 \% \\
& E 2=\frac{\lfloor 0.54-0.68\rfloor}{0.68} * 100 \% \\
& E 2=0.2030 * 100 \%=20.30 \%
\end{aligned}
$$$$
\text { E1Valid }
$$$$
\text { E2Valid }
$$ 


\begin{tabular}{|c|c|c|c|}
\hline No & Variabel & Validasi & Status \\
\hline \multirow[t]{6}{*}{3} & Intensitas hujan & โ17.32-18.01」 & E1Valid \\
\hline & & 18.01 & \\
\hline & & $E 1=0.0386 * 100 \%=3.86 \%$ & \\
\hline & & $\lfloor 10.31-10.75\rfloor$ & E2Valid \\
\hline & & 10.75 & \\
\hline & & $E 2=0.0413 * 100 \%=4.13 \%$ & \\
\hline
\end{tabular}

Detail hasil validasi pada Tabel 1 menunjukkan bahwa ketiga variabel yang divalidasi telah dianggap valid karena seluruh $E 1$ telah berada dibawah 5\% dan seluruh $E 2$ telah berada di bawah $30 \%$. Selain dari validasi menggunakan E1dan E2, model intensitas hujan dapat dihitung RMSE nya berada pada angka 8.4452 .

Tabel 2. Hasil prediksi dari model intensitas hujan

\begin{tabular}{cccc}
\hline & \multicolumn{3}{c}{ Intensitas Hujan $(\mathrm{mm} / \mathrm{h})$} \\
\hline Jan & 2018 & 2019 & 2020 \\
\hline Feb & 14.0 & 13.0 & 14.1 \\
Mar & 28.8 & 26.3 & 25.9 \\
Apr & 23.4 & 25.9 & 24.9 \\
Mei & 26.7 & 28.6 & 27.5 \\
Jun & 41.5 & 17.5 & 21.7 \\
Jul & 20.9 & 13.5 & 15.9 \\
Agt & 12.0 & 11.5 & 11.7 \\
Sep & - & - & - \\
Okt & 9.4 & 1.6 & 3.6 \\
Nov & 10.5 & 19.0 & 11.2 \\
Des & 24.1 & 24.9 & 29.0 \\
\hline
\end{tabular}

Model intensitas hujan yang dikembangkan telah dikatakan valid, oleh karena itu, dapat dilanjutkan ke prediksi untuk beberapa periode mendatang. Dalam penelitian ini dapat ditunjukkan prediksi untuk periode tiga tahun ke depan dengan hitungan rata-rata intensitas hujan harian (dalam bulan), yaitu tahun 2018-2020.

\section{KESIMPULAN}

Pendekatan sistem dinamik dapat digunakan untuk memodelkan memprediksi sistem apapun dengan variabel yang jelas. Dalam penelitian ini, sistem dinamik digunakan untuk memodelkan intensitas hujan harian rata-rata dengan mengintegrasikan faktor kelembaban dan temperatur. Model yang dikembangkan memiliki variabel kelembaban, temperatur, dan intensitas hujan yang dikategorikan dalam bulan karena didasarkan dari pengolahan data aktual yang telah didapatkan. Pada model yang dibuat validasi dilakukan pada variabel kelembaban, temperatur, dan intensitas hujan, secara keseluruhan telah dianggap valid menggunakan perbandingan rata-rata $(E 1)$ dengan hasil dibawah 5\% dan variasi amplitudo (E2) dibawah $30 \%$. Hasil validasi untuk variabel intensitas hujan menunjukkan nilai $E 1$ sebesar $3.86 \%$ dan $E 2$ sebesar 4.13. Selain itu RMSE pada variabel intensitas hujan yang didapat sebesar 8.4452. Hasil simulasi ini dapat digunakan untuk memprediksi intensitas hujan untuk tiga tahun mendatang yaitu 2018-2020.

\section{UCAPAN TERIMA KASIH}

Penelitian ini secara financial didanai oleh KementerianRiset, Teknologi, dan PendidikanTinggi (Kemenristekdikti) melalui program hibah Penelitian Dosen Pemula (PDP). Selain daripada itu, pengerjaan penelitian ini juga mendapatkan support dari Badan Meteorologi, Klimatologi, dan Geofisika(BMKG) Staklim Karangploso Malang danBadan Penanggulangan Bencana Daerah (BPBD) Kota Malang. 


\section{DAFTAR RUJUKAN}

Abidin, A. (2017, January 2). Kasus Bencana di Kota Malang Meningkat, Ini Daftar Wilayah Rawan Bencana di Lima Kecamatan. Surya Malang. Retrieved from http://suryamalang.tribunnews.com/2017/01/02/kasus-bencana-di-kota-malang-meningkat-ini-daftarwilayah-rawan-bencana-di-lima-kecamatan

Adhi, A. (2014, August 12). Hasil Survei, Kota Malang Nyaman tetapi Sering Banjir. Surya Online. Retrieved from http://surabaya.tribunnews.com/2014/08/12/hasil-survei-kota-malang-nyaman-tetapisering-banjir

Allan, R. P., Lavers, D. A., \& Champion, A. J. (2016). Diagnosing links between atmospheric moisture and extreme daily precipitation over the UK. International Journal of Climatology, 36(9), 3191-3206. https://doi.org/10.1002/joc. 4547

Barlas, Y. (1996). Formal aspects of model validity and validation in system dynamics. System Dynamics Review, 12(3), 183-210.

BPS Kota Malang. (2016). Kota Malang dalam Angka 2016 (Malang Municipality in Figures 2016). Malang: CV. Bima Media Mandiri.

Buishand, T. A., \& Brandsma, T. (1999). Dependence of precipitation on temperature at Florence and Livorno (Italy). Climate Research, 12(1), 53-63. https://doi.org/10.3354/cr012053

Chai, T., \& Draxler, R. R. (2014). Root mean square error (RMSE) or mean absolute error (MAE)? Arguments against avoiding RMSE in the literature. Geoscientific Model Development, 7(3), 12471250. https://doi.org/10.5194/gmd-7-1247-2014

Chang, H.-K., Tan, Y.-C., Lai, J.-S., Pan, T.-Y., Liu, T.-M., \& Tung, C.-P. (2013). Improvement of a drainage system for flood management with assessment of the potential effects of climate change. Hydrological Sciences Journal, 58(8), 1581-1597. https://doi.org/10.1080/02626667.2013.836276

Cong, R. G., \& Brady, M. (2012). The interdependence between rainfall and temperature: Copula analyses. The Scientific World Journal, 2012(3). https://doi.org/10.1100/2012/405675

Cooley, A., \& Chang, H. (2017). Precipitation Intensity Trend Detection using Hourly and Daily Observations in Portland, Oregon. Climate, 5(1), 10. https://doi.org/10.3390/cli5010010

Dube, A., Ashrit, R., Ashish, A., Sharma, K., Iyengar, G. R., Rajagopal, E. N., \& Basu, S. (2014). Forecasting the heavy rainfall during Himalayan flooding-June 2013. Weather and Climate Extremes, 4, 22-34. https://doi.org/https://doi.org/10.1016/j.wace.2014.03.004

Fadli, M. (2012). Prediksi (Nowcasting) Curah Hujan Pagi dan Siang Hari di Wilayah Jakarta dengan Model ANFIS (Prediction (Nowcasting) Rainfall Morning and Daylight in Jakarta Region with ANFIS Model). Megasains, 3(2), 61-76.

Frei, C., Schär, C., Lüthi, D., \& Davies, H. C. (1998). Heavy precipitation processes in a warmer climate. Geophysical Research Letters, 25(9), 1431-1434. https://doi.org/10.1029/98GL51099

Hayat. (2014). Implementasi Kebijakan Penataan Ruang Terbuka Hijau. Jurnal Ilmu Administrasi Negara, 13(1), 43-56. Retrieved from http://ejournal.unri.ac.id/index.php/JIANA/article/view/2366

Hiteshri, S., Subimal, G., \& Subhankar, K. (2017). Improving Global Forecast System of extreme precipitation events with regional statistical model: Application of quantile-based probabilistic forecasts. Journal of Geophysical Research: Atmospheres, 122(3), 1617-1634. https://doi.org/10.1002/2016JD025489

Khedhiri, S. (2015). Artificial neural network for forecasting rainfall pattern in Prince Edward Island, Canada. International Journal of Environmental Studies, 72(2), 331-340. https://doi.org/10.1080/00207233.2014.961311

Khidir, A. M., Adlan, H. H. A., \& Basheir, I. A. (2013). Neural Networks forecasting architectures for rainfall in the rain-fed Sectors in Sudan. In International Conference on Computing, Electrical and Electronics Engineering (ICCEEE) (pp. 700-707). Khartoum, Sudan.

Kigawa, S. (2014). Techniques of Precipitation Analysis and Prediction for High-resolution Precipitation Nowcasts. The Japan Meteorological Agency, 1-15. Retrieved from https://www.jma.go.jp/jma/en/Activities/Techniques_of_Precipitation_Analysis_and_Prediction_devel oped_for_HRPNs.pdf

Lepore, C., Veneziano, D., \& Molini, A. (2015). Temperature and CAPE dependence of rainfall extremes in the eastern United States. Geophysical Research Letters, 42(1), 74-83. https://doi.org/10.1002/2014GL062247

Lyneis, J. M. (2000). System dynamics for market forecasting and structural analysis. System Dynamics Review, 16(1), 3-25.

Morin, E., Krajewski, W. F., Goodrich, D. C., Gao, X., \& Sorooshian, S. (2003). Estimating Rainfall Intensities from Weather Radar Data: The Scale-Dependency Problem. Journal of Hydrometeorology, 
4(5), 782-797. https://doi.org/10.1175/1525-7541(2003)004<0782:ERIFWR>2.0.CO;2

Pabalik, I., Ihsan, N., \& Arsyad, M. (2015). Analisis Fenomena Perubahan Iklim dan Karakteristik Curah Hujan Ekstrim di Kota Makassar. Jurnal Sains Dan Pendidikan Fisika (JSPF), 11(1), 88-92.

Pielke, R. A., Bluestein, H. B., Enfield, D. B., Wells, N. C., Cenedese, C., Davies, R., ... Loewe, F. P. (2018). Climate - Meteorology. Retrieved June 26, 2018, from https://www.britannica.com/science/climate-meteorology/Atmospheric-humidity-and-precipitation

Rajasekaram, V., McBean, G. A., \& Simonovic, S. P. (2010). A systems dynamic modelling approach to assessing elements of a weather forecasting system. Atmosphere - Ocean, 48(1), 1-9. https://doi.org/10.3137/AO931.2010

Richardson, G. P. (2013). System Dynamics. In S. I. Gass \& M. C. Fu (Eds.), Encyclopedia of Operations Research and Management Science (3rd ed., pp. 1519-1521). New York: Springer. https://doi.org/10.1007/978-1-4419-1153-7

Sasongko, D. (2017, October 2). Sektor Pariwisata Berperan Penting Mendongkrak Sektor Ekonomi. Merdeka.Com. Retrieved from https://malang.merdeka.com/kabar-malang/sektor-pariwisata-berperanpenting-mendongkrak-sektor-ekonomi-171002f.html

Schumacher, R. S. (2016). Heavy Rainfall and Flash Flooding (Vol. 1). New York: Oxford University Press. https://doi.org/10.1093/acrefore/9780199389407.013.132

Tekeli, A. E. (2017). Exploring Jeddah floods by tropical rainfall measuring mission analysis. Water (Switzerland), 9(8), 612. https://doi.org/10.3390/w9080612

Trenberth, K. E. (2005). The Impact of Climate Change and Variability on Heavy Precipitation, Floods, and Droughts. Encyclopedia of Hydrological Sciences, 1-11. https://doi.org/10.1002/0470848944.hsa211

Wahyuni, I., Adipraja, P. F. E., \& Mahmudy, W. F. (2018). Determining Growing Season of Potatoes Based on Rainfall Prediction Results Using System Dynamics. Indonesian Journal of Electrical Engineering and Informatics (IJEEI), 6(2).

Zhou, Q., Leng, G., \& Huang, M. (2018). Impacts of future climate change on urban flood volumes in Hohhot in northern China: benefits of climate change mitigation and adaptations. Hydrology and Earth System Sciences, 22(1), 305-316. https://doi.org/10.5194/hess-22-305-2018 